\title{
Desglossant la transformació epistemològica: una exploració en narratives constitutives de dissidència social
}

\section{Itemizing the epistemological transformation: an exploration in constitute narratives of social dissidence}

\author{
Albert Martín-i-Gómez; Joan Pujol Tarrés \\ Universitat Autònoma de Barcelona., albert.martin@uab.cat
}

\section{Historia editorial}

Recibido: $10 / 04 / 2012$

Aceptado: 07/02/2013

Paraules clau

Dissidència social

Subjecció

Socioconstruccionisme

Produccions narratives

\section{Resum}

En aquest article explorem el procés de transformació viscut per les persones dissidents a l'ordre social establert. Mitjançant aquesta recerca, pretenem visibilitzar quin tipus de relacions, interaccions i situacions han possibilitat o afavorit aquest canvi, i quines emocions i sensacions han envoltat aquest procés de canvi. La transformació epistemològica, d'aquell sentit que orienta i dota de coherència a la pròpia subjecció és el procés objecte d'estudi, i per a comprendre com es dóna aquest, emprem les produccions narratives biogràfiques com a estratègia metodològica. Localitzem les participants de les narratives en persones que practiquen quotidianament la dissidència, a les que s'accedeix per àmbits fragmentaris de dissidència a les relacions socials (econòmica, de parentiu, política i simbòlica). De les narratives extraiem tres elements significatius compartits que permeten versar entorn al procés de transformació: (1) la pertorbació en la transgressió de la censura, (2) la vivència d'incomoditats i paral-lelismes en el procés, i (3) el grup dissident com a comoditat i nova possibilitació.

\section{Abstract}

\section{Keywords}

Social dissidence

Subjection

Socioconstructionism

Narrative productions societies. This research visualises the relationships, interactions and situations that
This paper explores the transformations experienced by those positions of dissidence to the established social order in the context of contemporary Western facilitated or encouraged these subjective transformations along the emotional elements surrounding these changes. Using biographic narrative productions the research identifies "subjective epistemological transformations"; transformations in the principles guiding the understanding of social reality. People who practice economic, kinship, political or symbolic dissent in everyday practices are included as participants. These narratives draw three common elements that in the understanding of the transformation process: (1) the disturbing effect of censorship; (2) the experiences of discomfort between hegemonic and dissident experiences; and (3) belonging to a dissident group as a form of comfort and opening of new possibilities.

“Et les réserves imposées au plaisir excitent au plaisir de vivre sans réserves.”

Détournement d'André Bertrand

\section{Introducció}

La teoria social s'ha centrat tradicionalment en abordar la reproducció de l'ordre social, amb respostes que van des del contracte social fins a les normes socials compartides, deixant sovint en un segon pla la qüestió dels mecanismes que incideixen en la seva transformació. En aquest article realitzem una

Martín-i-Gómez, Albert y Pujol Tarrés, Joan (2013). Desglossant la transformació epistemològica: una exploració en narratives constitutives de dissidència social. Athenea Digital, 13(2), 103-120. Disponible a http://psicologiasocial.uab.es/athenea/index.php/atheneaDigital/article/view/Martin-i-Gomez 
aproximació a la forma en que la persona ${ }^{1}$ inicia, consolida i dóna sentit a una forma de viure diferent a la de la majoria, que dissenteix a l'ordre social establert, trencant amb unes anteriors pràctiques quotidianes hegemòniques. És en aquest sentit, en tant que transformació en les categories comprensives en la forma de conèixer, concebre i relacionar-se amb el seu entorn social, que hem optat pel terme "transformació epistemològica".

L'exploració doncs no es centrarà en el contingut concret de la pràctica dissident —el què- ni en les causes concretes del contingut concret — per què aquest què-. La recerca es dirigeix a explorar com es produeix el procés de canvi, de transformació epistemològica, parant especial atenció a la rellevància que tenen, en la constitució de les persones, les diferents interaccions viscudes. Es dirigeix a explorar com s'elaboren els processos de subjecció -la forma en com es vinculen les relacions de poder i les condicions socials en la constitució identitària- i els processos de subjectivació —la forma en com es construeixen i modelen les pròpies formes de pensar, sentir i fer- de la dissidència social. Així, analitzar subjectes que han experimentat una transformació epistemològica "efectiva", en el pensar-fer quotidià, constitueix un primer pas exploratori en la comprensió dels processos de constitució de les persones, les seves formes de percebre, interpretar, actuar i relacionar-se. És a dir, comprendre els elements constituents pels quals una persona esdevé el que és.

Aquesta recerca pren pertinència en el moment en què es considera que la infinitat, intensitat i diversitat d'interaccions que viuen les persones quotidianament dificulta, alhora que enfosqueix i emmascara, la comprensió causa-efecte dels propis processos constituents (dels processos de subjecció i subjectivació de les persones). Així, els objectius centrals que prenem per aquesta recerca parteixen de la voluntat d'identificar elements comuns i paral-lelismes vivencials en els processos de canvi epistemològic de les persones, així com d'identificar característiques de les interaccions o situacions viscudes que permeten o possibiliten aquest canvi. Analitzant aquests processos de subjecció i subjectivació volem contribuir a comprendre, identificar i visibilitzar la rellevància de les interaccions com a causes i efectes de les relacions socials (de poder) quotidianes.

En aquest abordament, la comprensió iniciada per la "sociologia del coneixement" entorn a la cultura o univers simbòlic és un punt de partida pel propòsit d'entendre les formes de constitució i vinculació social, entesa com (Luckmann, 1967) (1) orientació per a la relació amb el medi, amb una mateixa i amb la resta de persones; (2) quelcom que fa indissoluble el pensar i el fer; i (3) allò que cohesiona i envolta, alhora que és constituït i articulat per, les relacions socials (econòmiques, parentals i polítiques) que pauten i regulen la subsistència, la reproducció i la convivència en la comunitat.

Aquestes relacions socials són el que en la perspectiva sociobiològica o evolucionaria s'identifica amb els instints "fam", "sexe" i "violència", portant a localitzar l'explicació del comportament en elements fora de la societat (biologia, genètica, impulsos innats) i només modelats per aquesta (Pinker, 2002; Wilson, 1983). En la perspectiva psicoanalítica són les pulsions de "l'autoconservació", "plaer" i "destrucció", posant èmfasi en l'aspecte emocional inconscient de la persona (Freud, 1930/1970; Gomà, 1979). I en la tradició sociològica són les que s'han instituït en "mercat", "família" i "Estat", en tant que símbols estructuradors i mediadors d'aquestes relacions (Campillo 2001; Castells 1998; Luckmann, 1973). En aquest article es pren també en consideració la importància dels aspectes emocionals, alhora que els situem en les prohibicions i tabús de caire cultural i simbòlic, però no inconscient. Entenent les emocions com quelcom constitutiu no de les persones (ni les seves agències) sinó de les relacions socials que desenvolupen aquestes (Gergen, 1996).

\footnotetext{
${ }^{1}$ Utilitzarem la flexió femenina en comptes de la masculina quan ens referim tant al singular com al plural de l'ésser humà, fent referència a la persona.
} 
La perspectiva és, d'aquesta manera, diferent a les perspectives psicològiques tradicionals que emfatitzen els elements psicològics estables que es mantenen al llarg del temps (com, per exemple, les característiques de personalitat) o que es centre en esdeveniments traumàtics que són objecte de treball terapèutic. Es tracta, en aquest cas, de fixar-nos en esdeveniments que afecten significativament i que són reconeguts com a possibilitadors d'una visió més elaborada i conscient de la realitat que els envolta.

En definitiva, l'article es centra en la significativitat i l'efecte que tenen determinats esdeveniments en la constitució de la persona com a subjecte que percep, interpreta i actua en el context social que l'envolta. En aquest sentit, les premisses socioconstruccionistes ens permetran entendre-la com una entitat plàstica i contextual; fixant l'element explicatiu en les interaccions, la construcció de les emocions i la seva ubicació dins les relacions socials (de poder), i en els símbols que donen sentit a aquestes.

\section{Subjecció i relacions socials}

Partim de la comprensió que elabora Norbert Elias (1984/1989; 1989/1994) entorn a la persona com a capacitada per, i necessitada de, elaboracions simbòliques que la permetin orientar-se, comunicar-se i, a la fi, governar-se. És quan mitjançant aquests recursos simbòlics que medien les relacions amb una mateixa, les altres i l'entorn, es constitueix un univers simbòlic (o imaginari social) que permet a les persones conformar-se una determinada identitat i desenvolupar unes formes de relació concretes amb les demés i la natura. Per abordar les formes de subjecció —o constitucions identitàries-, i de l'univers simbòlic - formes d'orientació i comunicació, constitutives de, alhora que constituïdes per, les relacions entre persones-, utilitzem les eines comprensives de la perspectiva socioconstruccionista proposada per Kenneth Gergen (1992) i Tomás Ibáñez (1983; 2001).

El socioconstruccionisme reprèn les premisses de l'interaccionisme simbòlic (Blumer, 1981), on la dimensió subjectiva de la realitat social entra en consideració tant en (1) l'aparició dels significats a partir de la interacció amb les altres, com en que (2) l'acció de les persones es produeix en base a aquests significats. Per altra banda, comparteix les premisses del construccionisme de Peter Berger i Thomas Luckmann (1966/1988), com (3) la rellevància del llenguatge en la construcció i producció de significats, més enllà de la concepció de codi neutre de comunicació; i (4) la historicitat dels significats (construccions instituïdes) que envolten tota interacció entre les persones d'una comunitat, és en la repetició quotidiana que es legitimen i sedimenten esdevenint un determinat ordre social i definint un marc de possibilitat.

Aquest procés de legitimació i definició d'un marc de possibilitat, tant en termes de vinculació social com de la pròpia subjecció, és el que Karl Marx i Friedrich Engels (1846/1987) definiran com a una de les funcions de la ideologia. Entesa com el sistema d'idees o representacions que una persona o classe social tenen sobre elles mateixes i del lloc que ocupen en el món i en la història. La rellevància de l'aportació és caracteritzar el procés com a no neutral, amb la propietat de sotmetre als interessos particulars d'una(es) classe(s) social(s) dominant(s) posseïdora dels mitjans d'execució de poder, generant i imposant els seus simbolismes per assegurar-se i perpetuar-se en el domini.

Des del socioconstruccionisme (Ibáñez, 2001), en canvi, es rebutja la concepció de l'interaccionisme simbòlic de l'agència individual com a espai on es negocien dialècticament significats i determinacions a l'hora d'actuar, o la concepció de Berger i Luckmann de la socialització estructural com a forma de transmissió del sentit/coneixement en el que les persones mantenen un paper passiu. La perspectiva socioconstruccionista compren que (5) és en la interacció entre persones on es produeix la transmissió o conformació de la subjecció, ni en l'agencia reflexiva individual ni en la socialització estructural. 
En aquest espai d'interacció entre significats és on prenen forma (6) les relacions de poder o dominació social. El socioconstruccionisme introdueix que les creacions socials dels significats que medien les nostres pràctiques estan inserides en relacions de poder, limitant (i també permetent) les definicions possibles (Ibáñez, 1983). Unes relacions de poder que són inherents a tota relació social dins l'entramat relacional constitutiu tant de la comunitat com de la subjecció de la persona.

Aquest procés de subjecció (o assumpció activa) donat en aquestes relacions socials impregnades per lògiques de poder no neutrals constitueix un dels elements que composen el biopoder de Michel Foucault (1976/1992), on s'hi afegeix l'economia política dels cossos a partir de pràctiques disciplinars. Un mecanisme inherentment relacionat amb la comprensió de la societat com a sèrie d'interdependències entre persones, com a teixit relacional, que trenca amb la concepció clàssica del poder com quelcom que es posseeix per passar a comprendre'l com a relació, com quelcom que s'exerceix.

El poder, però, no només s'estableix en la relació, en tant que no neutral, sinó que també configura la pròpia subjecció, no només el marc de possibilitat d'acció sinó també en la possibilitat de pensar quelcom fora de la convenció/norma. Així es pot contemplar l'omnipresència del poder, doncs "el poder está en todas partes; no es que lo englobe todo, sino que viene de todas partes" (Foucault, 1976/2009, p. 98), fent que les persones ens desenvolupem i ens constituïm a partir d'aquest poder, a partir del llenguatge, la gramàtica i les pràctiques del poder. Doncs el poder produirà el propi saber constitutiu de la persona, produirà allò pensable (Foucault, 1976/1992), i aquella gramàtica a partir de la qual comprenem i donem sentit a la nostra existència quotidiana.

En la ubicació de la persona en la xarxa de relacions socials, la subjecció és l'acte de sedimentació i reconeixement pel qual a partir de les relacions viscudes (Gergen, 1992) i interpel-lacions, s'identifica amb el que ha estat sent cridada a identificar-se. La interpel-lació és un acte enunciatiu performatiu en tant que constitueix la persona, tant per la forma de nominació com per l'exigència del reconeixement que estableixen les coordenades d'identificació (Althusser, 1970/1977). La interpel-lació és una forma per la qual les relacions de dominació actuen sobre les persones per convertir-les en objectes que prenen part en les relacions de poder i en subjectes de la seva pròpia lògica relacional de poder. Es tracta de la identificació amb una posició dins les relacions socials (de poder) que estructuren/medien la societat, subjectant a les persones en el lloc que se li ha assignat, i assumint de forma activa els continguts associats a aquest (pràctiques i significats socials).

Així, la constitució identitària acaba unint un nom (classe treballadora, dona, gai, immigrant, jove, etc.) amb un conjunt de subjectes, i no fruit d'una sèrie de característiques essencials compartides invariables en el temps, sinó de l'acte mateix d'interpel-lació i identificació amb aquell nom (Córdoba, 2003). Per a comprendre les diverses constitucions identitàries (fragmentàries), i com interseccionalment subjecten a les persones, s'utilitza la comprensió de la perspectiva de xarxes de Michael Mann (1986/1991)2. Partint d'aquesta perspectiva, Antonio Campillo (2001) revisa les relacions socials de poder concretades per Mann, establint-les en les tres relacions socials abans establertes: (1) relacions econòmiques ${ }^{3}$, (2)

\footnotetext{
${ }^{2}$ La perspectiva de Mann s'estructura en dos concepcions principals: (1) les societats no com a sistemes socials, com a totalitats, sinó com a xarxes relacionals; i (2) les societats com a múltiples xarxes de poder, que es superposen i s'interseccionen, que es discerneixen en relacions de poder social.

${ }^{3}$ Són les que regulen l'apropiació, producció i distribució dels recursos naturals, per assegurar la subsistència de les persones, són les formes d'organització del treball per al cobriment de les necessitats bàsiques. Aquestes relacions en les actuals societats contemporànies estan mediades mitjançant la institució/símbol del mercat. Aquesta dota de propietat per a l'apropiació i compravenda, tot bé material/natural o servei, convertint-se aquests en propietats privades, valorades en capital en funció de les seva utilitat, rendibilitat i eficàcia (Campillo 2001).
} 
relacions de parentiu i (3) relacions polítiques ${ }^{5}$; i considerant (4) l'univers simbòlic, com quelcom les articula i cohesiona ${ }^{6}$.

Paral-lelament a aquestes adscripcions identitàries particulars, en les relacions que la persona desenvolupa en les societats contemporànies occidentals es possibiliten unes interaccions, variades, inconnexes i impredictibles (Gergen, 1992), fruit de les particularitats de l'actual època postmoderna. És a partir de la ubicació dins les xarxes/relacions socials de poder que viuen quotidianament les persones que acaben definint en cadascuna unes pautes de comprensió, emoció i acció dins l'univers simbòlic hegemònic de la societat/comunitat que habita (Córdoba, 2003). Aquest esquema producte d'una determinada subjecció —intereseccional— i constitució identitària(es) —fragmentàries— determina una gramàtica, unes eines lingüístiques i afectives, possibilitada i constituïda en l'experimentació quotidiana dins aquesta xarxa relacional.

Des d'una sensibilitat semblant vers les formes de constitució identitàries, es poden trobar varis estudis al voltant de les identitats fragmentàries que constitueixen la persona: en les relacions econòmiques (Mora, 2007), en les relacions de parentiu (Butler, 1990/2007) i en les relacions polítiques (Billig, 1995/2006; Mignolo, 2000). Estudis que es fixen en les implicacions de la interpel-lació identitària com amb la relació amb les diverses estructures (enteses com a formació simbòlica constituïda per les continues interaccions i pràctiques socials que li donen sentit i existència): capitalisme, patriarcat $\mathrm{i}$ "estatalisme". Des d'aquests estudis, les diverses identitats van variant en funció de les diferents interaccions que la van subjectant i performant, doncs parteixen d'una perspectiva comprensiva on el subjecte no apareix com una entitat unificada i homogènia (Gergen, 1992), sinó com una pluralitat d'identitats fragmentàries.

Les interaccions que vinculen i subjecten a les persones estan articulades mitjançant símbols i significacions (Elias, 1989/1994) i aquests han de ser compresos de forma no neutral (Foucault, 1976/1992; Marx i Engels, 1846/1987). Aquestes vinculacions socials regides per símbols són les que es comprenen com a determinants de la gramàtica, de les eines lingüístiques i afectives, d'allò pensable i allò no pensable (la prohibició, el tabú i la inexistència cultural). Segons Foucault (1976/2009), la lògica del tabú i la censura cultural està prescrita a '"'ordre" del llenguatge, de les relacions de poder, i aquesta adopta tres formes diferents que es retroalimenten i que produeixen la pròpia subjecció de les persones: afirmar que allò no està permès (prohibició); impedir que allò sigui dit (tabú); i negar que allò existeixi (inexistència). Aquestes tres formes entrelligades conformen, mitjançant el mecanisme foucaultià "saberpoder", la censura cultural, que porta a reprimir emocions i comportaments "desviats" o "no-racionals".

\footnotetext{
${ }^{4}$ Són les que regulen la convivència entre sexes i generacions, per assegurar el manteniment i cohesió de la comunitat, són les formes de filiació, amistat, sexualitat, de combinació entre els vincles de consanguinitat i afinitat, que fan possible la vinculació afectiva, el desig i el plaer. Aquestes relacions en les actuals societats contemporànies estan mediades mitjançant la institució/símbol de la família. Aquesta es conforma a partir de l'afiliació consanguínia, a partir del nucli familiar "nuclear" (pare mare - fills/es) (Campillo 2001). Aquestes relacions s'articulen de forma patriarcal, a partir d'una sexualitat heterosexual, on només es concep l'agrupació familiar a partir de la unió entre el sexe home i el sexe dona en relació monògama i indissoluble (excloent possibles variants sexuals no dicotòmiques).

${ }^{5}$ Són les que regulen les formes de resolució de conflictes i de presa d'acords, tant a l'interior d'una comunitat com en les relacions entre diferents comunitats, per assegurar la convivència entre persones, són les formes d'instituir la dignitat humana i la governabilitat. Aquestes relacions en les actuals societats contemporànies estan mediades mitjançant la institució/símbol (jurídicoadministrativa) de l'Estat. Aquesta es conforma a partir de la reglamentació d'allò que està bé i allò que està malament en la convivència (Campillo 2001). Aquestes relacions s'articulen a partir d'un sistema de presa de decisions jeràrquic entre representants (parlamentaris deliberadors, jutges) i representades. Una jerarquia establerta a partir d'unes eleccions de delegació de la presa de decisions, mitjançant l'agrupació en partits polítics.

${ }^{6}$ Campillo (2001) no ho considera una quarta tipología de relació, sinó més aviat allò que les articula entre sí i els hi proporciona una determinada legitimació i coherència cultural i simbòlica.
} 
La quotidianitat, emparada en la convenció de la "norma" desenvolupa la multiplicitat de lògiques que constitueixen aquest ordre social; un ordre social que és remogut ocasionalment per pràctiques socials imprevistes que generen potencialment interpel-lacions pertorbadores de l'ordre en que viu el subjecte; turbulències socials que, seguint a Alison Jaggar (1989) incideixen en l'esfera emocional del subjecte. La possible sedimentació subjectiva d'aquestes interrupcions irracionals (en tant que fora del llenguatge sistèmic o hegemònic) obren la possibilitat de constituir una nova lògica que resisteix, o dissenteix, de l'hegemonia "racional", del comportament "normal" o sistèmic.

La prohibició queda invisibilitzada si estem sotmesos a ella, que no inconscient (en el sentit psicoanalític). És per això que l'experimentació viscuda en el moment de la transgressió, l'angoixa sense la qual no existiria la "prohibició", la transgressió de la prohibició, és l'experimentació del pecat, l'experimentació del tabú (Bataille, 1957/1997). La transgressió no nega la norma; l'afirma, la supera i la completa. Georges Bataille diu que els tabús i les prohibicions no van lligats a la intel-ligència ni a la racionalitat (sí a la consciència), sinó a la sensibilitat passional i a la irracionalitat emocional.

Doncs en l'objecte de passió humana el que varia són els camins pels quals l'abordem, ja que aquest té els més variats aspectes, però el seu sentit només és penetrat quan s'aconsegueix percebre la seva profunda coherència (Bataille, 1957/1997), quan són desxifrades i transgredides aquestes prohibicions i tabús produïts en les relacions socials de poder que ens vinculen i ens constitueixen. Quan aquestes emocions no convencionals són viscudes aïlladament poden produir confusió, incapacitat d'anomenar aquesta experiència, i inseguretat sobre el propi jo. Quan són compartides i validades per altres a partir, per exemple, de la interacció amb grup d'afins, es crea la base per formar una subcultura definida per percepcions, normes i valors contra-hegemònics. Construint aquesta base fora dels marcs conceptuals dominants, aquestes emocions poden ser política i epistemològicament subversives (Jaggar, 1989).

En aquest sentit, la possibilitació del "pensar altrament" depèn de les situacions i interaccions viscudes que han conformat la subjecció o identitat(s) de les persones. Constituint-se, així, una forma de "desprendre's d'una mateixa" (Gómez, 2004) que suposa, a través de les modificacions o interpretacions de les pràctiques, deixar de ser el que som (qüestionar un mode de ser subjecte) per a començar a ser d'una altra manera (produint noves formes de subjectivació). Aquesta variació de la subjecció implica qüestionar les normes establertes, les gramàtiques que el determinen i les instàncies que el fonamenten, convertint la subjectivació en l'espai de conflicte (de contradiccions, d'incomoditats, de resistències) més que en un lloc d'identitat essencial.

\section{Narratives de dissidència social}

Tenint en compte la comprensió que la subjecció de les persones és constant i infinita (Gergen, 1992), per abordar els canvis identitaris i de subjectivació profunds, i les vivències $o$ interaccions que han propiciat tals canvis, prenem en consideració la lectura que fa Juan Luís Alvarez-Gayou (2003) sobre la fenomenologia. La fenomenologia es caracteritza per centrar-se en l'experiència personal, descansant en quatre conceptes claus: la temporalitat (el temps viscut), l'espacialitat (l'espai viscut), la corporeïtat (el cos viscut) i la relacionalitat (la relació humana viscuda). És a dir, pren en consideració els àmbits històrico-contextuals de l'espai-temps, l'àmbit comprensiu semiòtic-material i considera que les persones estan vinculades amb el seu món (univers simbòlic-gramàtica comprensiva), posant èmfasi en la seva experiència viscuda, la qual apareix en el context de les relacions amb objectes, persones, successos i situacions. 
Segons Alvarez-Gayou (2003) les investigacions que realitzen anàlisis fenomenològics (1) busquen el significat de l'experiència (la vivència); (2) emfatitzen la intencionalitat de la consciència, és a dir, que les experiències es basen en la memòria, la imatge i el significat percebuts des del moment present; (3) estudien com una persona experimenta un fenomen viscut; (4) elaboren preguntes d'investigació que explorin el significat que les persones confereixen a l'experiència, i sol-liciten que se'ls hi descriguin les experiències viscudes quotidianament; (5) obtenen informació mitjançant l'entrevista dels qui han experimentat el fenomen que estudien; i (6) es convida a l'entrevistada a reflexionar sobre temes que no havia considerat del fenomen.

Aquesta caracterització de la perspectiva comprensiva fenomenològica (espai-temps, semiòtic-material i experiència viscuda) ens permet enllaçar amb les aportacions teòriques de Donna Haraway (1997/2004) al voltant del "coneixement situat", que parteix de considerar que el coneixement es construeix a partir de connexions i interaccions parcials entre múltiples posicions materials i semiòtiques. Coneixements parcials que sorgeixen d'ubicacions i articulacions particulars (interaccions de les persones) en continua transformació. Es tracta d'encarnacions (i visions) en les que la posició des de la qual es "mira" defineix les possibilitats de lectura i acció (Montenegro i Pujol, 2003). És a dir, permet posicionaments en que només algunes veritats, sensibilitats, percepcions, vivències transcendentals, són possibles; possibilitats per determinats contextos de producció de coneixement.

Així, hem recorregut a les produccions narratives per a recollir testimonis de persones amb pràctiques dissidents quotidianes, per tal d'explorar la significativitat de les diferents vivències $i$ experiències que transcendeixen i pertorben l'estabilitat simbòlica i gramatical que estructura la seva coherència existencial i identitària. És una tècnica que permet aprofundir i elaborar un relat entorn a les emocions i sentiments personals que han envoltat i transcendit l'experiència viscuda, considerant que la relació i la interacció són elements fonamentals per a la comprensió dels processos de subjectivació i de transformació del sentit.

Després de la transcripció íntegra d'entrevistes semi-estructurades, s'opta per textualitzar-les - convertir la transcripció en un relat- de forma conjunta amb l'entrevistada amb la finalitat de reconstruir el sentit de les trajectòries biogràfiques. És una forma de mantenir la singularitat de les diverses veus, generant relats unitaris de manera que el text resultant reconstruís les diverses trajectòries relacionades amb la transformació epistemològica. Aquesta particularitat de les produccions narratives respon a la necessitat d'evidenciar la rellevància de l'eix temporal (successió d'estadis i experiències vitals) com la dimensió explicativa dels processos a analitzar (Biglia i Bonet-Martí, 2009).

Les produccions narratives comprenen el coneixement com una producció fruit d'aquesta connexió parcial entre posicions, és una producció empírica (que no anàlisi d'aquesta) creada i negociada entre la comprensió de la investigada i de la investigadora. Aquesta producció empírica no pot, per tant, pretendre "representar" la realitat, sinó que aposta per la difracció, per a l'obertura d'espais diferents de comprensió i producció de significats. És una metàfora sobre el mètode de producció de dades que complexifica el coneixement, que trenca amb la dicotomia inductiu-deductiu, doncs afirma que el relat d'un fenomen -el material empíric- es crea des d'una posició situada (des d'un context de producció) mentre nega que es doni des de la capacitat d'accedir a una realitat des de la pura individualitat i de forma neutral o objectiva.

Partint de la perspectiva dels coneixements situats de Haraway (1997/2004), la localització de les participants en la creació de les narratives biogràfiques recau en la identificació de persona dissident com aquella que desenvolupa una pràctica quotidiana diferent (i que es contraposa, en forma d'alternativa) a l'ordre de relacions socials de poder establertes, que anteriorment eren practicades per 
aquesta. Localitzarem les participants de les narratives en persones que viuen i han viscut processos de dissentiment que poden proporcionar i crear, per tota aquesta experiència emocional viscuda, una forma d'entendre el món diferent a l'hegemònica. Les narratives obren una visió de com s'ha viscut i es viu aquesta diferència en les relacions socials, complementada per la revisió bibliogràfica, és a dir, el coneixement produït des de les diferents narratives remet a les connexions entre diverses explicacions entorn al camp de la transformació epistemològica.

La localització de les participants la realitzem en base a la divisió fragmentària de les diferents relacions socials: (1) relacions econòmiques, (2) relacions de parentiu i (3) relacions polítiques, així com (4) culturals/simbòliques, en tant que allò que cohesiona i dóna sentit la intersecció entre les altres. Partint d'aquest criteri classificador, la selecció de les participants respon, primerament, a la pertinença d'aquestes a un col-lectiu que practica de forma quotidiana una dissidència a una de les relacions socials fragmentàries. Les participants de les narratives, ho són en tant que formen part d'un collectiu dissident, és a dir, d'un collectiu que desenvolupa una pràctica quotidiana relacional diferent a l'hegemonia, de forma contraposada i erigint-se com a alternativa relacional, en les relacions econòmiques, de parentiu $\mathrm{i}$ polítiques. Pel que fa al collectiu que dissenteix a l'ordre cultural o simbòlic es selecciona un que desenvolupi i promogui pràctiques "artístiques" i subversives, en el sentit de pertorbar la coherència simbòlica i existencial hegemònica.

En segon terme, i desvinculant la pretensió de representar a la resta del grup al que pertany, per seleccionar la persona concreta ens hem basat en el factor que aquesta mantingui unes responsabilitats fortes i regulars en el col·lectiu corresponent. Així les participants de les narratives són "membres actives i estables" que aporten recursos a la organització del grup (econòmics, temps, esforç militant), que assisteixen a reunions, participen de comissions, que formarien part del "nucli dur" (González i Barranco, 2007). Així s'assegura la participació de persones que ja han desenvolupat el procés de transformació epistemològica que s'estudia, són persones que ja practiquen la dissidència social de forma quotidiana.

Finalment l'elecció específica d'aquests col-lectius, i de les persones concretes de cadascun d'aquests, partint de les condicions i característiques requerides i definides, són seleccionades tant per l'accessibilitat al col·lectiu per part de la investigadora com per la viabilitat i disposició mostrada tant pel grup com per la persona. Així, dels col-lectius als que s'ha tingut accés i han mostrat disposició a participar, les participants seleccionades per a la producció de les narratives formen part dels següents grups: en les relacions econòmiques el centre social de Can Masdeu ${ }^{7}$ (N1); en les de parentiu la Colllectiva feminista Les Tisores ${ }^{8}$ (N2); en les polítiques l'Assemblea de Joves del Poblenou ${ }^{9}$ (N3); i amb

\footnotetext{
${ }^{7}$ Al Centre Social rururbà de Can Masdeu (2010), okupat des de 2001, hi viuen unes 25 persones i basen la seva autogestió i autoabastiment en la recuperació dels usos tradicionals hortícoles i forestals, i una repoblació i plantació d'arbres fruiters. En aquests horts comunitaris hi participen unes 80 persones, on conreen mitjançant una gestió col-lectiva dels recursos naturals (aigua, terra, llavors, etc.). S'hi desenvolupa un bar on es serveix a preus econòmics menús vegetarians, tot elaborat de manera artesana i casolana gairebé sempre a partir de productes ecològics (no transgènics), locals, de temporada i/o de comerç just. Can Masdeu també compta amb una "botiga" de roba gratis, promovent un consum material i un cobriment de necessitats mitjançant l'intercanvi o la donació sense el valor monetari pel mig. Més informació: www.canmasdeu.net

${ }^{8}$ La Col•lectiva feminista Les Tisores (2010) és un collectiu format per dones i lesbianes que cerca el trencament amb la sexualitat heteronormativa. Les formes de dissidència sexual que es generen i es promouen es fan mitjançant activitats o tallers tant de caràcter intern com extern, que permeten a les pròpies integrants l'experimentació de pràctiques lesbianes. Unes pràctiques que permeten l'experimentació de noves sensacions i emocions que subverteixen el model de relació sexual heterosexual i el model de parentiu patriarcal que se'n desprèn, lligat a la reproducció, a la família nuclear i a la monogàmia. Més informació: lestisores.blogspot.com

${ }^{9}$ L'Assemblea de Joves del Poblenou (AJP-CAJEI, 2010) és un col-lectiu juvenil, conformat per joves d'entre 15 i 25 anys del barri barceloní del Poblenou. Les decisions es prenen per consens, pretenen promoure el debat i la participació sobre com construir un barri a partir de la solidaritat i la cooperació, i on siguin les pròpies veïnes les que decideixin el barri que volen; promovent una democràcia participativa allunyada de la representació i delegació en la presa de decisions. Més informació: www.jovespoblenou.cat
} 
pràctiques subversives amb l'hegemonia simbòlica el collectiu Espai en blanc ${ }^{10}(\mathrm{~N} 4)^{11}$. Cal matisar que alguns d'aquests collectius poden desenvolupar formes de relació dissidents en d'altres relacions socials fragmentàries, però en aquesta classificació com en l'abordament de les narratives ha prevalgut tant l'activitat social desenvolupada com la reivindicada pel col·lectiu.

Les produccions narratives donen compte de l'experiència singular dels subjectes, la comprensió final resultant, però, és producte de les connexions parcials entre totes elles. Aquesta connexió amb les participants, no s'expressa únicament en els fragments en que es cita explícitament algun passatge sinó en la totalitat del text. En aquest sentit, s'intenta inferir significats -en la forma- que transcendeixin la mera i directa manifestació textual -en el contingut- de les participants en les seves narratives. Una inferència que no busca trobar quelcom ocult entre les línies del text, sinó que intenta parlar de les experiències del subjecte des del subjecte, i no sobre ell (Martínez-Guzmán i Montenegro, 2009).

L'anàlisi consisteix en explorar i visibilitzar l'experiència dissident, desglossant els processos i paral-lelismes comuns viscuts en les narratives, centrant-nos en la forma narrativa i no tant en el contingut explícit dels textos; és a dir, tractar de construir equivalències en el "com es viu", en les connotacions del relat, i no tant en el "què es viu", l'aspecte purament denotatiu del mateix. L'anàlisi respon a un protocol d'etapes i processos d'operació amb els textos, començant per una primera fragmentació temàtica i una posterior consideració —catalogació- dels elements amb significació de cada dimensió (Ruiz Olabuénaga, 1996). A través de la consideració dels elements significatius de cada "dimensió" transversal en les diverses narratives, és possibilita un procés d'interpretació i re-figuració de la teoria, conjugant nous elements creats i elements prèviament considerats. És a partir d'aquest procés de fragmentació per "estructures narratives" dels textos i la "reconstrucció" mitjançant els elements significatius que se'ls passa a organitzar i donar sentit a través de criteris d'equivalències de les diferents narratives, de similitud i diferència, amb la finalitat de poder produir una nova visió condensada de les dades treballades.

Així, a partir de l'assemblatge ${ }^{12}$ entre teoria/epistemologia desenvolupada i les narratives, es poden desglossar tres elements o estructures narratives significatives a tenir en compte en la comprensió d'aquest procés de transformació del sentit. Aquests tres elements o dimensions del procés els anomenem: (1) la pertorbació en la transgressió de la censura; (2) la vivència d'incomoditats $i$ paral/lelismes en el procés; i (3) el grup dissident com a comoditat i nova possibilitació.

\footnotetext{
10 Espai en Blanc (2010) és una aposta collectiva per tal de re-pensar les relacions socials quotidianes entorn a aquells simbolismes que vertebren i vehiculen les formes de pensar, conèixer, sentir, percebre, interpretar i relacionar-se de les persones. És un grup que emergeix amb la intenció de pensar formes d'actuació que permetin "obrir escletxes i forats" en els donats per descomptat, en l'univers simbòlic hegemònic que estructura la vida quotidiana de les persones. Espai en blanc conjuga en aquestes reflexions l'activisme i l'acadèmia, el discurs i l'acció, les idees i les experimentacions. Les seves formes d'acció provenen de les aportacions de la pràctica situacionista, actualitzant i renovant tècniques com les performances (la creació i interpretació de situacions d'impacte), els happenings (on les activistes interpreten un paper i actuen sense guió pre-establert) o els detournements (la difusió d'eslògans que juguen amb la transgressió del significat hegemònic). Més informació: www.espaienblanc.net
}

11 Narrativa 1 (N1), membre de Can Masdeu. Entrevista realitzada el 20 de maig de 2011.

Narrativa 2 (N2), membre del Col•lectiva Feminista Les Tisores. Entrevista realitzada el 28 d'abril de 2011.

Narrativa 3 (N3), membre de l'Assemblea de Joves del Poblenou - CAJEI. Entrevista realitzada el 10 de maig de 2011.

Narrativa 4 (N4), membre d'Espai en blanc. Entrevista realitzada el 27 d'abril de 2011.

${ }^{12}$ El procés comprensiu que emergeix a continuació és fruit de la pròpia interpretació i anàlisi. Una interpretació contrastada i compartida per terceres persones investigadores socials del grup d'investigació FIC (Fractalidades en Investigación Crítica) del Departament de Psicologia Social de la Universitat Autònoma de Barcelona. Aquesta revisió del procés d'anàlisi es realitza amb la pretensió de dotar de credibilitat, transferència, consistència i confirmabilitat el tractament del material empíric creat (Guba i Lincoln, 1989). 
A l'hora de construir i definir aquestes dimensions a partir de les diferents narratives s'ha pres en consideració: en la dimensió (1) quelcom relacionat amb impactes narrats, en referència a relacions, situacions o persones amb les que s'ha interaccionat que han fet viure en les participants "un abans i un després"; en la dimensió (2) s'ha pres en consideració la referència a sentiments viscuts en la quotidianitat de la diferència de la seva vida vers la resta de persones amb qui es relacionava, incomoditats i malestars per la incomprensió o pels continuats conflictes amb la "normalitat"; i finalment, en la dimensió (3) s'ha tingut en compte aquella part dels relats on el grup dissident prenia un paper rellevant en les seves vivències grupals, i tot el que això comportava i significava en la participant.

\section{Elements del procés de transformació epistemològica}

Un primer abordament de les narratives creades permet realitzar una comprensió articulada en aquests tres elements significatius a considerar, que travessen les narratives i permeten una nova comprensió del fenomen. Es connecten a partir de la tensió entre semblança i diferencia entre elles (Montenegro i Pujol, 2003), difereixen en la seva identitat (o dissidència social fragmentària) però hi ha llenguatge $i$ experiències compartides i parcials.

La transformació en les formes de conèixer, interpretar i relacionar-se dels subjectes dissidents a l'ordre social establert s'evidencia en el procés de canvi epistemològic; un procés narrat de forma temporal però no s'ha de comprendre de forma lineal i progressiva. Es narra a partir de moments pertorbadors $i$ d'impacte; de patiment de contradiccions i incomoditats que romanen en paral-lel a la dissidència que es practica.

Considerant que la subjecció que conforma a les persones es realitza a partir d'interaccions quotidianes, i que aquestes relacions, influències i situacions són les que van desenvolupant formes de conèixer, sentir i relacionar-se — de subjectivació-; aquestes han de ser enteses com part a tenir en compte per a la comprensió d'aquest procés conformador de la pràctica dissident. Aquestes interaccions conformadores desenvolupen unes determinades sensibilitats possibilitadores de pertorbació o de transcendència quan es viuen formes - situacions o relacions- epistemològiques diferents. Seguint aquesta lògica, s'hauria de situar l'inici de la conformació d'una subjecció dissident en l'inici del cicle vital, però aquí no es pretén establir un inici estricte del canvi, aquí s'aborden els punts d'ancoratge identificats per la persona (a partir de les entrevistes semi-estrucutrades) i que esdevenen un procés de canvi "efectiu" (pensar i actuar) dissident.

Així però, hi ha algunes expressions a les narratives que deixen entreveure que la persona havia viscut unes interaccions passades possiblitadores de desenvolupar unes sensibilitats entorn al dissentiment a les relacions socials hegemòniques. L'N3 per exemple, narra com d'adolescent es sentia molt atret per les rebel-lies, quan estudiava "història" a l'institut recorda especialment l'interès i emmirallament vers les lluites de les minories, del moviment obrer o de l'alliberament nacional. Aquestes són unes sensacions d'inquietuds o d'emmirallament que poden possibilitar un desenvolupament en la comprensió i empatia vers la dissidència. En altres narratives s'expliciten dubtes o incomoditats vers les formes relacionals hegemòniques com l'N2 que d'adolescent anava a llocs d'oci estàndard (discoteques) i, a diferència de les seves amigues, es rebotava davant de certes actituds dels nois.

\section{La pertorbació en la transgressió de la censura}

En totes les narratives es destaquen records que relaten van ser origen de moltes reflexions en el moment de viure'ls, i que constitueixen el que seria la transgressió a la "censura cultural" (Foucault, 
1976/2009). I seguint la concepció de viure interaccions passades possibilitadores de desenvolupar sensibilitats entorn al dissentiment és quan es pot enllaçar amb la vivència d'una situació, interacció o relació d'impacte per a la persona i per a la seva subjecció.

Aquests impactes que pertorben l'estabilitat existencial i explicativa de la subjecció podrien associar-se a l'erotisme que trenca amb l'ordre, el que en la consciència de la persona posa en qüestió el propi jo, la pròpia subjectivació. Bataille (1957/1997) entén per "erotisme" el desequilibri pel qual la persona es qüestiona a sí mateixa conscientment, és a dir, el desequilibri pel qual una qüestiona i transgredeix els límits o "censura" (tabús, prohibicions i inexistències) de la cultura que l'ha constituït i vinculat com a tal, que l'ha subjectat i identificat.

Les narratives reflecteixen com alguns referents culturals o educatius esdevenen pilars explicatius de les experiències a partir de les quals les persones amb aquestes interaccions passades possibilitadores identifiquen vivències personals que s'han emmirallat o originat en aquests. Per exemple es fan referències significatives a professores de l'institut o universitat (N3 i N4), pel-lícules (N4), lectura de llibres i autores (N1, N2 i N4). Aquestes identificacions vivencials, que causen un abans i un després, possibilitades per un desenvolupament previ d'una sensibilitat que els fes sensibles a ser pertorbats per aquestes, a la fi provoquen mutacions en la subjecció i subjectivació.

A banda d'aquestes formes d'impacte que posen "nom" (N2) a sensacions d'incomoditat, hi ha d'altres situacions que sí podrien rebre més categòricament el nom de "ruptura epistemològica" o de transgressió, per fer allò que no està permès (prohibició), per dir allò que està impedit (tabú), o per afirmar allò que no és possible (inexistència). La narrativa centrada en les relacions polítiques defineix com a "interruptor" el fet de freqüentar un centre okupat amb els amics i trobar-se en un espai de llibertat on no se'ls hi demanava ni DNI ni explicacions pel que fessin (N3). O com quan, un cop els van desallotjar d'aquell centre social okupat $\mathrm{i}$ intentaven okupar un nou espai, va haver de fer accions illegals (trencar vidres), amb els riscos que suposava (N3). També recorda com a importants impactes que trencaven aquesta "censura cultural", en aquest cas política/normativa, viure directament sent menor d'edat les manifestacions del 2001 contra la cimera del Banc Mundial a Barcelona.

Crec que aquell va ser un moment clau d'inflexió per a mi. En aquelles manifestacions vaig veure de tot, accions directes, atacs directes contra la policia, vaig veure'm a prop de ser detingut, era un sidral bastant generalitzat. Va ser una experiència molt "heavy" que em va generar reaccions de tot tipus, de ràbia i por alhora. [...] Em trobaria en espais de plena impunitat policial. Recordo que anava amb companys de la meva edat (uns 16 anys) i la Policia Nacional ens va parar i registrar i vam patir petits abusos però significatius que em van marcar. [...] es van quedar el pedaç [estelada independentista catalana] perquè deien que era un símbol anticonstitucional i respecte l'encenedor, com que era menor d'edat, em van preguntar - ¿no fumarás porros?, com amenaçant d'avisar als meus pares [...] recordo també la impotència (N3, membre de l'Assemblea de Joves del Poblenou - CAJEI. Entrevista realitzada el 10 de maig de 2011).

La narrativa de la dissident en les relacions sexuals/parentiu, recorda com li va impactar que un company noi proposés que un llibret que havien d'editar estigués escrit tot en femení: "Em va impactar tant perquè mai havia escoltat l'existència de l'opció d'escriure en femení, com perquè hagués estat un noi el qui ho fes" (N2, membre del Col-lectiva Feminista Les Tisores. Entrevista realitzada el 28 d'abril de 2011).

Aquestes dues situacions narren impactes que causen sorpresa en les participants, però també transcendència que es reflectirà en les seves futures quotidianitats, pertorbant i mutant les seves 
subjeccions i subjectivacions (formes de pensar-se una mateixa les pròpies subjeccions). Aquestes situacions representen records que marquen "un abans i un després" en les narratives vitals, que a la fi han pertorbat l'estabilitat existencial i epistemològica del moment passat.

L'N2 relata com posteriorment, amb ja un recorregut de "militància" feminista, va viure "el que passa" en espais restringits per a dones i lesbianes, dels que en principi n'estava en contra, comprovant com allà hi passen coses que mai passarien en llocs mixtes. Relata que va veure com les noies podien donar la seva opinió o estar de festa sense trobar-se amb el rebuig. Es sentia més lliure de pensar, fer i compartir. Però sobretot el canvi vers els llocs mixtes era el no sentir-se observada sota la mirada de l'home com a únicament objecte sexual, el com miren quan una noia balla o no balla, o balla de determinada forma 0 altra; en aquests espais podia fer més lliurement el que en aquell moment li venia més de gust (N2).

Per altra banda, i en aquest sentit d'impacte, per transgredir allò no pensable I'N1 narra com quan tenia 16-17 anys, quan ja es considerava i es feia dir "ecologista", un amic de la família que estava en un grup ecologista li va dir que ell no s'havia fet ecologista per salvar animals (pels que ella tenia major sensibilitat), ell s'havia fet ecologista per salvar-se a ell, als seus fills i als humans, que eren els qui veritablement estaven en perill d'extinció. Allò, reconeix que li va fer connectar les seves sensibilitats vers l'ecologisme i vers les desigualtats socials.

Aquestes narracions d'impactes viscuts que han pertorbat la linealitat o coherència existencial (de possibilitat racional) evoquen a l'emotivitat viscuda, a les emocions que es viuen en la transgressió. Narren l'erotisme de posar-se a una mateixa en joc, trencant els propis límits de coherència epistemològica existencial. Aquestes emocions pertorbadores ho són en tant que escapen de la lògica racional que dóna compte de l'experiència vital viscuda fins al moment o de la pròpia subjecció o formes de conèixer i relacionar-se.

\section{La vivència d'incomoditats i paral·lelismes en el procés}

Una de les condicions que es generen en les societats contemporànies, fruit de la intensitat i diversitat de relacions i interaccions quotidianes d'una època postmoderna, és el que Gergen (1992) caracteritza com a saturació social. Una condició en la que viuen les persones quotidianament que comporta un nou fenomen social que anomena "multifrènia", basat en la multiplicitat d'investidures del jo, en la multiplicitat de formes en que les persones som interpel-lades de diferents maneres i contínuament, en diferents entorns i contextos.

El procés de transformació epistemològica estudiat consisteix en el trànsit del que seria una subjecció anàloga amb l'ordre social establert, que segueix les seves lògiques de comprendre i actuar, a unes formes que el qüestionin o directament el dissenteixin en la quotidianitat. És en aquest procés en el que totes les narracions emfatitzen el fet de viure'l ple de contradiccions, de sensacions d'incomoditat quotidiana i de paral-lelismes entre pràctiques dissidents en alguns espais o amb algunes persones $\mathrm{i}$ pràctiques hegemòniques en d'altres i amb altres.

En aquest sentit l'N4 reconeix patir i ser conscient d'aquestes contradiccions. Narra sentir-se intel-lectualment subversiu i transgressor però sense traslladar-ho a la pràctica:

La meva vida no és que sigui trencadora i això per mi és un càrrec de consciència bastant pesant. Les meves formes de pensament són unes i, en canvi, la pràctica és molt estàndard. [...] En aquest sentit visc una mica esquizofrènicament (N4, membre d'Espai en blanc. Entrevista realitzada el 27 d'abril de 2011). 
També explica com, sent músic, cantant i compositor, la música que fa no és trencadora a nivell formal però si conceptual, però que des de fora no se sentiria atret pel que fa (N4). Aquesta mateixa lògica també la segueix el dissident en les relacions polítiques quan narra el pudor o vergonya que pateix al mostrar o explicar la seva dedicació i orientació política en els àmbits laborals/acadèmics. En aquest sentit diu viure dificultosament la doble vida entre quotidianitat i implicació política doncs sol se li fa més difícil; li costa, se n'amaga i és un desengany per a sí mateix (N3). Aquesta és una vivència que genera frustració, diu buscar excuses o justificacions molt sovint, quasi a diari. Viu en paral-lel unes pràctiques i concepcions quotidianes hegemòniques en uns entorns i dissidents en altres: "Podríem dir que no he sortit de l'armari. En segons quins llocs estic dins l'armari" acaba narrant (N3, membre de l'Assemblea de Joves del Poblenou - CAJEI. Entrevista realitzada el 10 de maig de 2011).

La dissident a les relacions econòmiques explica com anar a viure a Can Masdeu va ser un trasbals, li va trencar els esquemes del projecte de vida, doncs no s'havia plantejat tot el que comportava l'autogestió. Ella volia seguir treballant vuit hores diàries a fora la casa però vivint en comunitat i de forma més ecològica. Haver de renunciar a la seva carrera professional per incompatibilitat de temps li va suposar molts dilemes i molts plors. La seva vocació professional era el que l'enclavava en una vida més convencional (N1). Aquell procés de malestar, entre que va entrar a Can Masdeu i va deixar la feina, narra que:

Va ser tot un procés interior de menjar-me l'orgull a l'hora d'agafar les feines menys reconegudes de la professió. Així com replantejar la meva vida professional en termes de treballar per treure diners i passar-m'ho bé mentre treballo, assumint que no seré la professional que volia ser (N1, membre de Can Masdeu. Entrevista realitzada el 20 de maig de 2011).

Per altra banda, en la narrativa dissident respecte de les relacions de parentiu apareixen contradiccions que s'expliciten en termes de no tallar-se el cabell quan la resta de noies del col-lectiu ho va fer, o a I'hora de decidir com sortir vestida de casa (N2), qüestions molt relacionades amb la reflexió del tipus de feminitat que volia viure. També narra com en la majoria d'àmbits, fins i tot en espais dels moviments socials, se sent malament a l'hora d'haver d'insistir sempre en la poca sensibilitat de gènere. Moltes vegades ha viscut com es muntava un enrenou, un debat molt fort, amb conseqüències que al final acaben afectant personalment. Al final acaba resignant-se i fent veure que no ho ha escoltat, fer-ho passar de llarg i evitar maldecaps. Doncs es troba que a tot arreu ha d'estar sempre reivindicativa, on la seva opinió sempre és massa radical, i on s'acaba sentint tractada de boja (N2). Així mateix, la dissident a les relacions econòmiques acaba narrant que està farta de ser sempre la rara i sentir-se una mica marciana quan explica com viu la vida (N1).

Aquesta sensació viscuda destaca per la seva transversalitat en les narratives, és una autodefensa davant la incomoditat de les relacions mantingudes amb gent no sensible amb les seves dissidències. Així l'N4 narra com amb el pas del temps ha anat prenent consciència de la seva diferència vers la resta, de que anava a contracorrent, i en aquest procés s'ha hagut de reafirmar en els seus postulats, arribantse a convertit en intolerant amb altres formes de viure (N4). En un sentit semblant l'N1 diu que a vegades directament ja no hi parla amb segons qui, o menteix, perquè no hi ha temps per explicar la veritat, narra que si expliqués la veritat en la majoria dels casos no ho entendrien, necessitaria molt de temps per ferse comprendre (N1).

Les vivències quotidianes d'aquest procés de transformació, en les formes de viure, mantenen el malestar o incomoditat existencial mentre es manté aquesta relació paral-lela en ambients socials anteriors (laboral, acadèmic o espais d'oci convencional) a l'inici de practicar el particular tipus de 
dissidència. Aquesta quotidianitat contradictòria i plena de dubtes entorn a l'actitud vers "l'exterior hegemònic" contrasta, en canvi, amb la quotidianitat o les sensacions o aportacions en que pot consistir el propi grup dissident de pertinença. De totes formes cal tenir present que al voltant d'aquestes sensacions també existeixen conflictes relacionats amb la pràctica dissident vers la normativitat dissident del collectiu en qüestió.

\section{El grup dissident com a comoditat i nova possibilitació}

En aquesta formació experiencial, en contrast amb la resta d'àmbits, es posa de manifest la convergència entre diferents practicants dissidents, creant un espai de comoditat. Les persones acaben preferint els espais amb persones afines, també dissidents, en la quotidianitat i no haver-se de trobar amb incomprensions vers les seves pròpies pràctiques. Alison Jaggar (1989) diu que quan s'experimenten sensacions no-convencionals de forma aïllada fins $i$ tot poden produir dubtes entorn a la pròpia salut, no en canvi si són compartides i validades per altres, que pot arribar a donar peu a la formació de subcultures no hegemòniques — com serien els casos dels col-lectius dels que pertanyen les participants de les narratives-.

És molt clarificadora la narració que fa la dissident a les relacions de parentiu al voltant de la vivència del canvi de llocs d'oci i companyies que freqüentava:

Per ser lesbiana, ni en els espais d'oci et diuen res, no s'atreveixen, en canvi per ser feminista si que m'he sentit dir de tot. Al principi no ho portava gaire bé i em "ratllava", després ha arribat un punt en que em reafirma. Amb el pas del temps m'he anat fent amb altra gent amb la que m'he sentit més còmoda (N2, membre del Collectiva Feminista Les Tisores. Entrevista realitzada el 28 d'abril de 2011).

Segueix explicant com selecciona els llocs on va, de tal manera que ja no es troba amb conflictes de gènere. Són espais amb gent més sensibilitzada amb les relacions de poder, majoritàriament només hi van dones o es tracta d'ambients femenins. Ha acabat optant per anar a on es troba més a gust, un procés del que diu haver-ne estat plenament conscient, escollint i seleccionant el tipus de gent (N2). Aquest canvi conscient d'entorns i relacions també és present en la narració de l'N4 quan explica com ha anat filtrant la gent amb la que s'envolta i amb la que manté relació. Si no comparteix res amb algú, fora; intenta envoltar-se de gent que el recolzi (N4).

En aquest sentit segueix la narració del dissident a les relacions polítiques quan explica com, amb el pas del temps, va anar perdent el contacte amb els amics de l'escola i institut, i en va anar fent de nous més relacionats amb la militància. A les anteriors amistats els hi interessen i parlen d'unes coses amb les que una estona s'hi sentiria a gust, però el farien sentir buit en altres aspectes, doncs la seva dedicació personal a la política dista molt de les formes de viure d'elles (N3). A l'actualitat viu la comoditat amb la parella, la família propera, o amb les amistats i companyes de lluita que es barregen bastant. Són aquests espais i companyies els que fan que no visqui a diari la incomoditat i frustracions de les relacions hegemòniques que pràctica en l'àmbit laboral (N3).

En referència a la comprensió de Jaggar (1989) respecte el paper del grup com a espai possibilitador d'experiències i de compartiment d'inquietuds, el mateix dissident a les relacions polítiques explica com quan va sol intenta que no el vegi ningú fent pintades o enganxant adhesius, en canvi si va amb el col-lectiu inclús li agrada que el vegi segons qui, diu que la força del collectiu l'empodera (N3). La narració de la dissident a les relacions de parentiu dóna peu a assentar aquesta concepció del grup tant com a comoditat com a possibilitador d'experimentar inquietuds i contradiccions. La participant narra com 
en les assemblees del col-lectiu on comparteixen experiències i vivències quotidianes va aparèixer una sensació grupal de "desig", de grup de comoditat (N2), i va ser on van poder experimentar inquietuds que compartien sobre pràctiques sexo-afectives tant teòriques com més corporals (N2). Narra com per a ella formar part del col-lectiu de dissidència ha suposat viure moltes contradiccions a mida que anaven reflexionant $i$ experimentant sobre els límits patriarcals en la societat i en elles mateixes. Especialment pel que fa a la seva sexualitat com a la seva feminitat, la seva pròpia forma de ser i sentir-se dona (N2). En aquesta sintonia, la dissident a les relacions econòmiques narra com fins que no va entrar a Can Masdeu no va poder dur a terme un consum de roba mitjançant l'intercanvi (N1), cultivar i produir la pròpia alimentació (N1), ni un munt d'idees per fer més coses de les que feia amb anterioritat (N1).

S'ha de considerar com el grup dissident es converteix en el grup d'afins per a les persones que dissenteixen a l'ordre social establert, tant per trobar en ell un grup de persones on no topar-se amb la constant discussió o incomprensió, com per compartir inquietuds i plegades experimentar noves experiències possibilitadores de nous horitzons i de noves dissidències (ara potser també amb el propi grup dissident). El grup exerceix el paper de possibilitador de transgredir els límits de la censura cultural que una persona sola i aïllada mai podria, i de compartir i, alhora, fer possible l'erotisme de l'experimentació de transgredir allò prohibit, allò tabú i allò inexistent. Així el grup permet una nova possibilitació a ser sensible a més, i diferents, situacions discordants amb la norma, permet noves sensibilitzacions susceptibles de pertorbar i seguir trencant altres donats per descomptat de l'ordre social establert.

\section{Conclusions}

Les produccions narratives han servit de dispositiu per produir uns coneixements situats que han permès esbrinar, explorar, i aprofundir entorn al ventall de sensacions, emocions i experiències que envolten els processos viscuts per persones que dissenteixen quotidianament a determinades relacions socials de l'ordre social establert. Les conclusions de les quals no pretenen, mitjançant la mostra de participants dissidents, representar a cap tipus de població amb l'objectiu de generalitzar els resultats. Ans al contrari, la pretensió de la investigació és exploratòria, es tracta d'una primera aproximació al procés de transformació epistemològica, per tal d'ampliar el ventall d'elements a considerar, i començar a abordar l'anàlisi d'aquestes possibles regularitats identificades en el procés.

En aquest procés d'investigació hem pres com a punt de partida la comprensió de la persona com a subjecte (subjectat) sensibilitzat $i$ possibilitat de percebre $i$ interpretar una determinada vivència $o$ experiència de forma contextual i situada (espai-temps i semiòtic-material). Aquesta disposició o capacitat de ser sensible o ser susceptible de ser pertorbat per una interacció, o situació viscuda, concreta, depèn de les interaccions passades que han constituït i possibilitat a la persona d'una forma determinada. L'objectiu, però, d'aquesta recerca no és identificar el contingut concret d'aquestes possibles interaccions passades que possibilitarien el desenvolupament de formes epistemològiques sensibles amb formes que dissenteixen les relacions socials hegemòniques. L'objectiu és la comprensió del procés de transformació epistemològica, identificant elements que el constitueixen, que possibiliten o afavoreixen aquest canvi.

El procés explorat en aquesta investigació, encara que sigui narrat en una direcció acumulativa temporalment, no s'ha de comprendre com un procés lineal en el sentit evolutiu o progressiu del terme, ni com un procés tancat amb un inici i final delimitats. Es tracta d'un tram temporal de la vivència i conformació de la subjecció i subjectivació de les persones dissidents en el que identifiquem i desglossem tres elements comuns i transversals en els processos de transformació epistemològica. 
De les narracions de les diferents vivències que han estat originadores de reflexions i qüestionaments sobre la pròpia vida quotidiana, o sobre allò donat per descomptat, podem identificar un tipus d'interaccions que marquen "un abans i un després" en la comprensió de l'experiència vital de la persona -de l'experiència de sí-. Aquestes interaccions impactants (situacions, relacions, concepcions) pertorben emocionalment l'estabilitat vital (o simbòlica) pel fet de transgredir la lògica interpretativa de la pròpia experiència (la forma de sentir, actuar i pensar-nos a nosaltres mateixes -la subjectivació-). És en la pertorbació i qüestionament de la subjectivació que s'està produint la transformació o mutació de la subjecció. Doncs s'està transgredint allò que des de la subjecció era prohibit, era tabú o inexistent, allò que no era susceptible de ser pensat, dit o actuat. Aquests impactes són el desequilibri pel qual la persona comença a qüestionar-se conscientment la seva pròpia quotidianitat, al voltant de les seves relacions amb l'entorn, amb ella mateixa $\mathrm{i}$ amb les altres, unes relacions que l'havien subjectat $\mathrm{i}$ identificat fins al moment. Un element que en aquest procés de transformació anomenem com a (1) la pertorbació en la transgressió de la censura.

El ventall d'emocions pertorbadores que envolten aquestes interaccions d'impacte no són susceptibles a la raó (o racionalitat) de l'anterior lògica de coherència interpretativa de la pròpia existència — de la subjectivació-. Doncs aquestes emocions es desenvolupen al voltant de les "ruptures epistemològiques", giren al voltant de la vivència de les contradiccions, de les sensacions d'incomoditat i insatisfacció. Són unes emocions que viuen la contradicció i incomoditat del contrast o parallelisme entre pràctiques (o subjeccions) dissidents en alguns espais, i pràctiques (o subjeccions) hegemòniques 0 "normalitzades" en d'altres. Element anomenat com a (2) la vivència d'incomoditats i paral/lelismes en el procés.

Finament, és en la vivència d'aquestes sensacions de contradicció vers els paral-lelismes quan el grup d'afins dissidents es converteix en l'espai en el que la persona pot desenvolupar de forma còmode les seves inquietuds i experimentar les relacions dissidents a l'ordre social. Així el grup dissident pren el paper de ser l'espai on la persona deixa de viure sensacions d'incomprensió i incomoditat, i novament possibilita una nova subjecció a ser transgredida, i un context on compartir inquietuds i experimentar noves formes de relació que poden tornar a posar en qüestió la pròpia subjectivació. Les noves interaccions que viu la persona (amb les possibles conseqüents desestabilitzacions de la subjectivació) són les que poden permetre la nova o següent mutació de la subjecció. I per tant, en el grup es possibilita el desenvolupament de noves sensibilitats per a ser susceptible de ser pertorbada novament per futures interaccions, a les que potser amb anterioritat haurien estat intranscendents $\mathrm{i}$ no pertorbadores. Un darrer element anomenat com a (3) el grup dissident com a comoditat $i$ nova possibilitació.

Al reflexionar sobre els elements identificats, només la pertorbació en la transgressió de la censura podria implicar un pervenir incert envers l'hegemonia existent. La transgressió de la censura es pot produir bé per (a) un acte conscient de transgressió, que pressuposa i reafirma el coneixement de la transgressió que es vol realitzar; o (b) una transgressió no intencionada de l'hegemonia que tindrà o pot tenir com a conseqüència una penalització social no esperada. En aquest últim cas trobem un efecte constitutiu de dissidència incert i, per tant, es produeix una complexificació de l'acte de dissidència pel que fa a la imprevisibilitat del seu efecte en el subjecte.

La dissidència, alhora, implica una posició de contradicció i d'inestabilitat. A pesar de que cert grup pot legitimar localment l'experiència i les pràctiques dissidents, aquestes es produeixen en un context social relativament advers. Aquest element assenyala les pràctiques de cura i comoditat que han de tenir en compte els grups, en tant que possibilitadors i constitutius de punts de dissidència. També apunta a les 
contradiccions que qualsevol posició dissident s'ha d'enfrontar a l'hora de desenvolupar la seva experiència vital. I com per a les persones que viuen o practiquen la dissidència, l'aparició del grup d'empara permet la consolidació de les experiències de dissidència social generades, tant en les formes de sentir com de viure.

\section{Referències}

Althusser, Louis (1970/1977). Posiciones. Barcelona: Anagrama.

Alvarez-Gayou, Juan Luís (2003). Como hacer investigación cualitativa. Fundamentos y metodologia. Mèxic: Paidós.

Assemblea de joves del poblenou - CAJEl (2010). Extret el desembre de 2010 des de http://www.jovespoblenou.cat

Bataille, Georges (1957/1997). El erotismo. Barcelona: Tusquets.

Berger, Peter i Luckmann, Thomas (1966/1988). La construcció social de la realitat. Un tractat de sociologia del coneixement. Barcelona: Herder.

Biglia, Bàrbara i Bonet-Martí, Jordi (2009). La construcción de narrativas como método de investigación psico-social. Prácticas de escritura compartida. Forum: Qualitative social research, 10 (1), Art.8. Extret el novembre de 2010, des de http://nbn-resolving.de/urn:nbn:de:0114-fqs090183.

Billig, Michel (1995/2006). Nacionalisme Banal. València: Afers.

Blumer, Herbert (1981). El interaccionismo simbólico. Barcelona: Hora.

Butler, Judith (1990/2007). El género en disputa. El feminismo i la subversión de la identidad. Barcelona: Paidós.

Campillo, Antonio (2001). Variaciones de la vida humana. Una teoría de la historia. Madrid: Akal.

Can Masdeu (2010). Extret el desembre de 2010 des de http://www.canmasdeu.net

Castells, Manuel (1998). La era de la información. Vol.I La sociedad red. Madrid: Alianza Editorial.

Col-lectiva feminista "les tisores" (2010). Extret el desembre de 2010 des de http://lestisores.blogspot.com

Córdoba, David (2003). Identidad sexual y performatividad. Athenea Digital, 4, 87-96.

Elias, Norbert (1984/1989). Sobre el tiempo. México: FCE.

Elias, Norbert (1989/1994). Teoría del símbolo. Un ensayo de antropología cultural. Barcelona: Península.

Espai en blanc (2010). Extret el desembre de 2010 des de http://www.espaienblanc.net

Foucault, Michel (1976/1992). “Del poder de soberanía al poder sobre la vida”. A: Genealogía del racismo. Madrid: La Piqueta.

Foucault, Michel (1976/2009). Historia de la sexualidad: 1. La voluntad de saber. Madrid: Siglo XXI.

Freud, Sigmund (1930/1970). El malestar en la cultura y otros ensayos. Madrid: Alianza.

Gergen, Kenneth J. (1992). El yo saturado. Dilemas de identidad en el mundo contemporáneo. Barcelona: Paidós.

Gergen, Kenneth J. (1996). Realidades y relaciones. Aproximaciones a la construcción social. Barcelona: Paidós.

Gomà, Francesc (1979). Conocer Freud y su obra. Barcelona: Dopesa 2.

Gómez, Lucia (2004). Subjetivación y feminismo: Análisis de un manifiesto político. Athenea Digital, 5, $97-123$

González, Robert i Barranco, Oriol (2007). Construyendo alternativas frente a la globalización neoliberal. Resistencias juveniles en Catalunya. Revista de Estudios de Juventud, 76, 267-285. 
Guba, Egon i Lincoln, Yvonna (1989). Fourth generation evaluation. Newbury Park, CA: Sage

Publications.

Haraway, Donna (1997/2004). Testigo modesto, segundo milenio, HombreHembra conoce oncoratón. Barcelona: Eureca Media.

Ibánez, Tomás (1983). Poder y libertad. Barcelona: Hora.

Ibáñez, Tomás (2001). Psicología social construccionista. Mèxic: Universidad de Guadalajara.

Jaggar, Alison M. (1989). Love and Knowledge: Emotion in feminist epistemology. Interdisciplinary Journal of Philosophy, 32(2), 129-155.

Luckmann, Thomas (1967/1973). La religión invisible. Salamanca: Sígueme.

Mann, Michael (1986/1991). Las fuentes del poder social, I. Una historia del poder desde los comienzos hasta $1760 \mathrm{~d}$. C. Madrid: Alianza.

Martínez-Guzmán, Antar i Montenegro, Marisela (2009). Narrativas en torno al trastorno de identidad sexual. Prisma Social. Revista de ciencias sociales, 4, 1-44.

Marx, Karl i Engels, Friedrich (1846/1987). La ideologia alemanya. Barcelona: Laia.

Mignolo, Walter (2000). La colonialidad a lo largo y a lo ancho: el hemisferio occidental en el horizonte colonial de la modernidad. A Edgardo Lander, (Comp.), La colonialidad del saber: eurocentrismo y ciencias sociales. Perspectivas Latinoamericanas (pp. 55-85). Buenos Aires: Clasco.

Montenegro, Marisela i Pujol, Joan (2003). Conocimiento situado: Un forcejeo entre el relativismo construccionista y la necesidad de fundamentar la acción. Revista Iberoamericana de Psicologia, 37(2), 295-307.

Mora, Enrico (2007). Las dimensiones fragmentaria y performativa de las subjetividades de classe. Revista Universitas Psicológica, 6(1), 11-25.

Pinker, Steven (2002). La tabla rasa. Barcelona: Paidós.

Ruiz Olabuenaga, José I. (1996). Metodología de investigación cualitativa. Bilbao: Universidad de Deusto.

Wilson, Edward O. (1983). Sobre la naturaleza humana. Mèxic: FCE.

Este texto está protegido por una licencia Creative Commons.
Usted es libre de copiar, distribuir y comunicar públicamente la obra bajo las siguientes condiciones:
Reconocimiento: Debe reconocer y citar al autor original.
No comercial. No puede utilizar esta obra para fines comerciales.
Sin obras derivadas. No se puede alterar, transformar, o generar una obra derivada a partir de esta obra.
Resumen de licencia - Texto completo de la licencia

